\title{
Reinforcement of Character Education Love for the Living Environment based on Conservation School Model
}

\author{
Mohamad Syahri \\ University of Muhammadiyah Malang \\ msyahri@umm.ac.id
}

\begin{abstract}
In general, this the objective of this present research is to study and to describe the characters and the cultures of loving the environment comprehensively in supporting the sustainability of the renewable energy 'micro hydro' at Conservation Schools in Malang regency, so that any problems on the energy and spring water may be continuously solved. Different schools have different understandings in identifying plants that may bind water. From the results of the identification, there are a lot of types of plants that bind water. The strategies of reinforcing the characters and cultures of loving the environment are made through socialization: programs socialization, programs synchronization, and consolidation of the materials. The curriculum on the renewable energy is not available yet. The specific curriculum was made in cooperation between the Department of Forestry and Environment, the Department of Education and Culture, Observers/Actuators of the Environment, and the Higher Education.
\end{abstract}

Keywords: environment, curriculum, higher education

\section{INTRODUCTION}

A contemporary approach to character education at school provides students with ideas on their own moral education and the levels of self-orientation that have partly been influenced by the theories of cognitive development. [9] Civics education plays an important role in implanting the values. Since the corridor is valuebased, the values should be taught in either formal or non-formal education such as community civics [15]. Since education is implemented in the cultural and empowering processes, in order to create a learning condition that may be able to promote desires and good creativities and to support the empowerment for selfsuccess (in ngarso tung tulodho, in madro mangun karson, tut wuri handayani [13], modeling is in a great need.

Development is needed for either the present or future generations, so that the sustainable development should be made [17]). Then, as stated in the law, protecting the environment is an obligation, and conservation is a part of the management and the utilization of the environment resources [18]. Prosperity resulted from the utilization of the natural resources not only become the rights of the present but also future generations [1]. The results of the first year research showed that characters and cultures of loving the environment were still low. It is because many people had not understood of how to maintain and to preserve the environment well in order to assure the sustainability of the people' life. Moreover, the people in general also had not understood about any plants useful for the environmental preservation. As a result, the plants useful for human beings especially those for preserving the water resources were neglected [16].

The potency of the renewable energy "Micro Hydro" in Malang regency is very great, but at the moment the condition has not yet been optimally made use of. Meanwhile, the people's need for water availability is greater. If this condition is not early anticipated, it will greatly influence the quality of human beings. Water, a source of life for human beings, is a human main need that should be fulfilled. Therefore some understanding of the importance of changing the people's behaviors and characters should be made as soon as possible through some efforts to preserve water springs such as replanting any plants that may bind water as made by previous generation as the local wisdom.

On the basis of the explanations above, an alternative solution to the problem of characters and cultures of loving the environment to support the sustainability of the renewable energy "micro hydro" is to handle them seriously and sustainably. Building the characters and cultures of loving the environment is made through socialization and dissemination of the concepts of loving the environment at schools, and the arrangement of the renewable energy-based curriculum. The curriculum should be soon implemented in learning activities. Identification and dissemination of the plants that may bind water to support the sustainability of the renewable energy "micro hydro" should be made at the schools environment.

The main problem in building the characters and cultures of loving the environment in supporting the sustainability of the renewable energy "micro hydro" in Conservation Schools in Malang regency is low understanding of the people in managing and utilizing the environment cleanliness and low awareness of the people in administering and using the water springs properly. Therefore, unconventional strategies should be employed to improve the sustainability of the renewable energy "micro hydro". It should be done because at the early stage, it is impossible to directly change the people' cultures at schools frontally. So far, no research has been done on the characters and cultures of loving the environment dealing with the sustainability of the renewable energy 'micro hydro,' from the identification, 
the curriculum arrangement, to the institutional reinforcement concerning with the renewable energy at schools. Therefore, it is necessary to study it comprehensively. This present research was made in stages with the main theme of "Reinforcing the Characters and Cultures of Loving the Environment in Supporting the Sustainability of the Renewable Energy "Micro Hydro" at Conservation Schools in Malang City". In the third year the focus was made with the title of the "Strengthening the Educational Character of Taking Care the Environment in Conservation School".

\section{Character Education}

In character education, emphasizes the importance of three components of good characters namely moral knowing, moral feeling, and moral action. It is needed to make students able to understand, to feel and to act any good deed values simultaneously. For moral knowing, six points become the objectives of teaching the moral knowing: 2) moral awareness, 2) knowing moral values, 3) perspective taking, 4) moral reasoning, 5) decision making, and self-knowledge. For moral feeling, 6(six) points exist as the aspects of the emotion that should be able to be felt by someone to become human beings with proper characters: 1) 1) conscience, 2) self-esteem, 3) empathy, 4) loving the good, 5) self-control and 6) humility. Dealing with moral action, there are moral actions which are the outcomes from the other two components. In order to understand what encourages someone to act morally, three other aspects of characters should be observed: 1) competence, 2) will and 3) habit.

Mengawangi as the one one who triggers the character education in Indonesia has made noble characters to be taught to children, known as 9 pillars: 1) (love Allah, trust, reverence, loyalty; 2) responsibility, excellence, self reliance, discipline, orderliness; 3) trustworthiness, reliability, honesty; 4) respect, courtessy, obedience; 5) love, compassion, caring, empathy, generousity, moderation, cooperation; 6) confidence, assertiveness, creativity, resourcefulness, courage, determination and enthusiasm; 7) confidence, assertiveness, creativity, resourcefulness, courage, determination and enthusiasm; 8) kindness, friendliness, humility, modesty and 9) tolerance, flexibility, peacefulness, unity.

Based on the descriptions of the characters above, it is necessary to try to develop the character education of the nation through the environmental education at the elementary education, since this elementary education is the basis for developing characters of our students. It is because the condition of our life is apprehending, and the concern to the environmental preservation is getting low.

Mischief has appeared on land and sea because of (the meed) that hands of men have earned, that (Allah) may give them a taste of some of their deeds: in order that they may turn back (from evil) (the Noble Quran: ar-Ruum, 30:41). The meaning of the above verse shows the close relationship between human attitudes and the preservation of the environment in which human beings live. The balance of the ecosystem that will influence their continuation is an absolute prerequisite to create a harmonious life from either social, economic, or cultural aspects. An integrated and holistic development is an ideal step to create a harmonious and balanced ecosystem in the nature. In fact, the development is more oriented into or emphasized on the economic aspect, on such, and the humanistic values are ignored. The perspective of human beings on the environment (ecosystem) may be categorized into two types namely immanent (holistic) and transcendent. According to the holistic point of view, human beings may separate themselves from their surrounding bio-physic system such as animals, plants, rivers, and mountains. But they feel that there is a functional elation to the bio-physic factors so it will form one socio-physic unity. According to the transcendent point of view, life ecologically is a part of its environment, where human beings are separated from their environment, environment is considered as the resource created to be maximally exploited [5].

Dealing with the agenda for the environmental preservation, there are four issues to pay attention: 1)Pollution, among others air pollution, acid rain, climate change, water pollution, pollution caused by chemical material, industrial wastes, nuclear waste, and the like; 2) natural sources: among others deforestation, losing of genetic sources, land erosion and desertification, critical land problem, sea sources damage, land capability degradation, losing of agricultural land, and so on; 3 ) Urban areas, among others land use in big cities, environmental sanitation, fresh water, city growth management, social prosperity and education, dirty environment and housing, greening in big cities, and so on; and 4) Management: among others monitoring and reporting, investment analysis, cost-benefit analysis, cost effectiveness, risk analysis, also including AMDAL (Environmental Impact Analysis)in a project [12].

In encountering this so concerned condition, the world of education is trying to implement its learning to be integrated with the character values of this nation, including: 1) Be Religious: attitudes and behaviors which are obedient to the religion one believes in, tolerant to the other religions' ritual, and harmonious with the believers of other religions; 2) Be Sincere: behaviors which are based on any efforts oneself do in making oneself always able to be believed in his/her words, actions, and deeds; 3) Be Tolerant: attitudes and actions that respect to others' religions, ethnic groups, ideas, attitudes, and actions different from oneself; 4) Be Discipline: actions showing any behaviors that are ordered and obedient to various stipulations and regulations: a) Be Hard Work: behaviors showing some real efforts to solve various learning hindrances, duties and doing some works well; b) Be Creative: thinking and doing something to produce new ways or results from something one has possessed; c) Be Independent: attitudes and behaviors which are not easily dependent on other people to complete duties; d) Be Democratic: ways of thinking, behaving and acting that appraise one's rights and duties to be same with other's; e) Be Spirit of Nationality: ways of thinking, acting and perceiving that place if interest of nation and state above 
one's and groups' interest; f) Love the father land: ways of thinking, behaving and acting that show loyalty, care, and high respect to the physical, social, economic, and political environment of the nation; g) Be respectful to the achievement: attitudes and actions that encourage oneself to produce something useful for the community, and that acknowledge and respect others' success; h) Be communicative: actions that show some comfort with talking, associating and cooperating with others; i) love peace: attitudes, words and actions that cause other people to feel happy and secure with one's presence; j) like to read: habits to provide time to read various readings giving some good deeds for oneself; k) care about environment: attitudes and actions which always try to prevent any damages of the surrounding environments and to develop any efforts to improve any natural damages that have happened; 1) have social care: attitudes and actions that always want to give some assistance to others and people that need them; m) be curious: attitudes and actions that always try to know something to be learned, heard and listened to deeply and widely; n) be responsible: attitudes and attitudes to do some duties and obligations, that should be done for oneself, community, environment, state and One Supreme God [11].

\section{Environmental Education}

Environmental education should be developed on the basis of the basic concept of the environment applied for all types and channels of education of science from elementary to higher education levels. Education is not only formal but also non-formal and informal through either governmental/official institutions or by the non governmental organizations. The governmental institutions should be able to promote the integration between the attitudinal and behavioral wisdom in order to face any problems because of the natural order (earthquakes, volcanoes eruptions, and the like) or of any damages or loss due to the types of living creatures' behaviors including human beings. Then an integration should be made to reduce or to minimize any pollutions as human beings' deeds themselves [13].

The environmental management is implemented through the environmental education of which its mission is the education of the attitudinal, moral or spiritual wisdom in the reality of life behavior at present and in the future for the safety and prosperity of the ecosystem in which we live. Here, it is necessary to understand the reciprocal relationship among natural factors such as earthquakes, volcanoes eruptions, earth warming, thinning ozone layers functioning to filter ultraviolet light, acid rains and the like. Moreover, the ways of solving and also minimizing the possible impacts are also given.

A research finding the writers made dealing with the environmental education is as follows: the development of the national character education through the environmental education at elementary schools in Batu city was well implemented either in a monolytic and integrated way. The development of either the curriculum or the materials involved the Education Department and the Environment Office.

The environmental problem is moral one, namely the problem of human attitudes. Environment is not only a technical problem. The crises of our global ecology at present is the the problem of moral and character, a global moral crisis. Therefore, to solve the problems, it is the ethics and morality which is needed. It cannot be denied that various environmental cases happening at the moment, either globally or nationally, are mostly from human attitudes. According to Arne Naess [6] the environmental crises now may only solved by changing human perspectives and attitude of the nature fundamentally and radically. What is needed is a new life pattern or style which not only include one person, but also the culture of the people as a whole, meaning that the environmental ethics guiding human beings to interact in a new way in this universe. It can be stated that the crises of the global environment we encounter today are actually from the fundamental-philosophical faults we do in viewing or understanding about ourselves, the nature and the place of human beings in the whole ecosystem. The faults then may result in faulty attitudes towards the nature. Human beings are not right in viewing the nature and also in placing themselves in the context of the universe as a whole. And it is the beginning of all natural disasters we are experiences at present. Therefore, our understanding should also cover the understanding of our point of view and attitudes in interacting with either the nature or other humans being in the whole ecosystem. The faulty point of view is from an anthropocentrism ethics viewing human beings as the centre of the universe, and it is only human beings that have values, meanwhile the nature and anything in it merely functions to fulfill the human beings' interest and needs.

A modern society should protect the quality of the environment, biodiversity and also human life order. To do so, an effective mechanism including tight regulations, incentives, punishment, sustainable monitoring and evaluation of the environment is necessary/the basic values of our society at present is often materialistic in nature. To change it, it is necessary to have a comprehensive and complementary approach [8]. The environmental ethics should be socialize to the Indonesian people. If the society is aware of and follow the principles of the environmental ethics, the preservation of the environment and the maintenance of the biodiversity will work well.

The principles of the environmental ethics have been proved by a lot of traditional cultures in out country. They have succeeded in uniting and living harmoniously with their environment for centuries. In the traditional cultures. The ethics and norms in the society have encouraged individuals to be responsible for and to make use of natural resources efficiently. This condition should become the model and also the priority for the modern society today. But in fact, the greed shown by human attitude results in severe environmental damages. In the anthropocentrism approach, it is stated that the human 
beings' point of view of the environment has places human interests (economic, exceeding exploration and exploitation of the natural resources) in the environment as its centre.

The experts of the environmental economics have develop method to count the values of the environmental economics, but the values are merely the potential ones, substitutive values or also often called shadow price, such as the biodiversity values, genetic values (plasma nutfah) one of which serves as the raw materials for medicines. The condition is worsened by the time and place distance between the deeds and the impacts, while the benefits from the changes are directly enjoyed.

Dealing with the attitude of the society, it can be stated that culture might influence its attitude toward the environment. Human beings actually possesses some teachings to live harmoniously with their surrounding or their natural environment. The teachings are good viewed from either religion or cultural aspects. The attitude fully oriented to the environment will make human beings to behave in a greed way, as if anything belongs to them. For instance, a forest $\mathrm{i}$ exploited for their economic interest an sich without considering: (1)the need of the future generation in the context of economy and natural preservation, and (b) the need for saving the forest itself.

Attitude to life of some greed societies is paradox with the one taught by religions that human beings should live humbly. Religion is present to provide human beings with guidelines and right ways for human beings. As a results, religious persons should be demanded to give some teachings rooted from saving the environment. An argument of ethics is a valid reason to protect the environmental preservation and the biodiversity. This argument is from the values order of religions, philosophies, and cultures, so that they may be easily understood by most community members. Moreover, the argument to preserve the environment and the biodiversity may touch upon the people's instincts and good sides, and this argument arises as the appreciation to the life, nature, weaknesses, feeling of beauty, uniqueness, beauty of the world of life, belief in God's creation and greatness. The society often may accept them, at least most of the society may consider the argumentation in their belief orders [8].

The environmental education should be able to establish an integration between the attitudes and behaviors wisdoms to face any problems arising due to natural orders (earthquakes, volcanoes eruptions, and so on) causing damaging or losses due to the behaviors made by any types of living creatures, including human beings. Therefore, the Department of Education and Culture, Malang regency, in cooperation with the Department of Environment and Forestry, have tried to implement the Environmental Education by establishing a model school, "Conservation School"

\section{Previous Studies}

A research on "Reinforcing Characters and Cultures of Loving the Environment in Conservation Schoolss" has not been done yet, but to widen this discourse some relevant studies may be found out. A research [14] on the Managing the Green Open Space Based on the Actor Roles as an Effort to Realize the Sustainable City in Malang City states that a sustainable city cannot be separated from the concept of a sustainable development. In this case, the government is required to be able to arrange the space and to watch its implementation, besides solving any problems arising at present such as $\mathrm{CO} 2$ emission control and waste management. Dealing with the urban RTH (Green Open Space), in the Minister for Internal Affairs' Regulation No. 1 in the year of 2007 it is stated that the RTKP (Ruang Terbuka Hijau Kawasan Perkotaan) (Green Open Space in Urban Area) is a part of the open space of an urban area contained by all kinds of plants to support the ecological, social, cultural, economic and aesthetic benefits.

Then [3] in his research with the title of "Challenges of the Environment and Landscape of Urban Forest in Jakarta" states that grouping the function of urban forest should be in line with its form and structure that are visually created. The form and the structure may reduce the temperature, noisy, and dust, and may also increase humidity. The structure of a multi-stratum vegetation in this research proved to be the most effective way to prevent any problems in urban environment (Eco Learning Camp) as a model of value education. It is concluded that Eco Learning Camp as a model of value education may contribute to handling the environment and values crises.

\section{Problems in Renewable Energy "Micro Hydro"}

The crises of the environment has entered into a very worrying stage since the last three decades. Data show that around $29 \%$ land in this earth has been in the process of becoming desserts at the low, medium and serious stages. Meanwhile $6 \%$ may be classified into the process in a serious stage. Tropical forests covering $6 \%$ of the earth area posses $50 \%$ biodiversity of the existing amount of species, but 7.6 to 10 millions hectares per year of the forests have been destroyed [4] There are some factors to consider when creating the renewable energy "micro hydro" that will influence either the quality or the quantity. The factors are the decreasing water debit, the availability of plants that may store/bind water (Artocarpus and Vicus), the people's characters and culture about the importance of maintaining the environment, and the people's need for renewal energy micro hydro. The four factors are very influential in creating the renewable energy "micro hydro"[16].

The renewal energy micro hydro becomes a new hope for the people in Malang regency, because the water debit in this areas is getting low, whereas the people's need for water is higher and higher. This problem should be quickly and seriously handled, remembering that water is the main requirement for human beings and other living creatures in the world.

One of the alternatives to have new water springs is to provide plants that may store/bind water. The plants are the ones under the genus of Artocarpus and Vicus. In Malang regency, there are twenty kinds of plants that may store/bind water. 
It is necessary for the people to grow characters and cultures in keeping the environment in order to avoid any natural damages. Less understanding among the people about the importance of keeping the environment may result in the decreasing function of water springs the nature have been provided with. This low understanding may be seen from the people's indifference to the function of plants that may store/bind water, so that the people easily cut the trees for their short-term interest. It is through the Conservation Schoolss that the people's characters and cultures of loving the environment may be flourished and developed early, so that the sustainability of the renewal energy micro hydro may be maintained.

On the one hand, the people's high need for electrical energy and the limited capacity of the electrical energy available on the other hand makes the people's electrical energy unfulfilled. The availability of the electrical energy is not only needed to meet the people's daily need, but also to support their economy, remembering that since the economy has not optimally develop due to the limited electrical energy. Therefore, it is necessary to optimize the environment to sustain the sustainability of the renewable energy micro hydro to make the people's need for the electrical energy be met.

\section{METHOD}

This present research is descriptive qualitative in nature, which is principally focused on the investigation and the study of various literatures to implant the Characters of Loving the Environment at Model School, "Conservation Schools" in supporting the sustainability of the "Renewable Energy "Micro Hydro" in Malang regency. Identifying the concept of innovation and orientation to the theories of characters and environment, this research is designed to do two activities. The first activity is to collect the data on any efforts to describe the contexts of the theories of citizens, and of environment oriented, and the second one is to recognize and to describe the environmental education to support the sustainability of "Renewable Energy".

This research was made at a model school "Conservation Schools" at the 2015/2016 academic year. The data were collected using the following techniques: a) in-depth interviews, intended to get any information on the national character education through the environmental education, b) observations, aimed at collecting data in the field by scrutiny, where the researchers directly observed the research activities being examined [7]. Hence, it can be stated that observation is a technique employed to collect the data by focusing all attention on a research object using all senses. The researchers observed : 1) teachers' activities in teaching the environmental education, 2) students' activities in the teaching-learning process in the environmental education, 3) documentation: this technique was used to collect data from the Department of Education, on the curriculum, modules, and other notes related to the environmental education in the Conservation Schools.
The conclusion drawing or the verification is a process of examining and testing the validity of the collected data by analyzing them. Each datum collected was analyzed and verified until a pattern or a meaningful theme according to the research focused was discovered.

The types of the data this research needed included the primary and secondary data. The data sources (key informants) were the headmaster, the teachers, the school committee, the Department of Education and Culture and also the Department of Forestry.

Data analysis, according to [7] is a process of organizing and ordering data into patterns, categories and basic description units so that themes may be identified and the working hypotheses might be formulized. The method of the data analyses employed in this research is Glasser \& Struass's one, covering 1) data reduction, identification, and data coding; 2) data categorization; 3) synthesis; 4) making working hypothesis formulized in the form of drafts or the concept of implanting character of loving the environment at the model school, the Conservation Schools in supporting the sustainability of the renewable energy 'micro hydro' in Malang regency, East Java province.

The steps in the activities were as follows: 1) Data Reduction. At this stage, the researchers made a unit identification to describe the problems dealing with any efforts to implant the characters of loving the environment that had been made so far, covering: (a) the forms of activities,(b) the sources of activities, (c) the orientation of the implementation, (d) the application of the implementation and its problems. From these activities, the researchers tried to code each unit in accordance with the sources of the data; 2) Categorization. The activities the researchers made so far dealt with some efforts to select or the units which were the same in parts in accordance to the categories for the data reduced concerning the implanting of characters of loving the environment; 3) Making Synthesis. At this stage, the researchers tried to relate one category into another that had been formulated in order to get a picture to describe, especially the one dealing with the implanting the characters of loving the environment.

\section{RESULT}

On the basis of the observations in the field, interviews and the documented data, the following findings will be presented: Reinforcing Characters and Cultures of Loving the Environment in Supporting the Sustainability of renewable Energy Micro Hydro" at the Conservation Schools in Malang regency that consists of three sub section: 1) identifying any plants that may bind water, (b) describing strategies of institutional reinforcement of the renewable energy Micro Hydro at the Conservation Schools, (c) identifying the curriculum of the renewable energy micro hydro based on the local wisdom. 
Identifying any plants that may bind water in supporting the sustainability of the renewable energy "Micro Hydro"

Dealing with the identification of plants that may bind water, each target school has different understandings. Some schools may recognize the concerned plants, some cannot. From the results of the identification in the field, it is necessary to develop some types of plants in supporting the sustainability of the renewable energy 'micro hydro', they are among others: 1) Elo, 2) Beringin, 3) Gencrutan, 4) Cangkring, 5) Bendo, 6) Kluwih, 7) Pakel, 8) Jenar, 9) Aren, 10) Pring Petong, 11) Ori, 12) Jambu Alas, 13) Salam, 14) Apak, 15) Prih, 16) Bolu, 17) Nangka, 18) Sukun, 19) Genitri, 20) Gempol, 21) Pucung, 22) Trembesi, 23) Gondang, 24) Awar-awar,25) Kadot, 26) Pule, 27) Randu alas, 28) Randu gumbolo, 29) Dadap

Strategies of institutional reinforcement of the renewable energy Micro Hydro at the Conservation Schools in Malang regency

The Conservation Schools are from the Department of Forestry under the area of the protection of the forest land use, the section of the forest protection where the name of the activity is the elucidation of the people's awareness of the impact of forest damages. The term Conservation School is employed to distinguish it from Adiwiyata School under the responsibility of the Environmental Body. The conservation school is intended to help the provision of the facilities and infrastructures dealing with the building of students' characters and behavior towards the environment.

To realize a conservation school, strategies of reinforcing the characters are as follows: 1) the conservation school presented programs to the target schools. 2) the target schools presented the plan of building and developing schools and their either shortterm or long-term programs, 3) the conservation school synchronized its programs to the those of the target schools in accordance with planning of building and developing the schools. Then, the head of the forest protection added the strategies of reinforcing characters: seminars and trainings with the following materials: 1) the present condition and problems in the natural resources in Indonesia and in the world, 2) the design of the conservation school, 3) the innovation of creative learning and its implementation at school, 4) the technical guidance of planting trees (seedling garden at school). In line with the respondents' explanation, the head of the natural conservation added the following strategies namely giving techniques of 1) utilizing wastes, 2) conserving land and water practically and plainly, 3) recognizing biodiversity in the school environment, 4) probing the carbon absorption, and 5) practicing and implementing them gradually in line with the implementation of the activities.

Arranging the curriculum of the renewable energy micro hydro based on the local wisdom

From the result of the observation in the field, a specific curriculum containing the renewable energy micro hydro did not exist, except the materials on the environment, though it is still integrated with some subjects. The curriculum was made in cooperation between the Department of Forestry and Environment, the Department of Education and Culture, Observers/Actuators of the Environment, and the Higher Education.

\section{REFERENCES}

[1] Abdurrahman, Pembangunan Berkelanjutan Dalam Pengelolaan Sumber Daya Alam Indonesia, Badan Pembinaan Hukum Nasional Departemen Kehakiman dan Hak Asasi Manusia Republik Indonesia 2003.

[2] Christe, Anata, Yosep dan Lasina, Erawati, Dampak Kerusakan Lingkungan Akibat Aktivitas Pembangunan Perumahan, Jurnal Beraja Niti, ISSN: 2337-4608 Volume 2 Nomor 112013.

[3] Djamal, Irwan,Zoeraini, Tantangan Lingkungan dan Landsekap Hutan Kota, Jakarta: Bumi Aksara, 2005.

[4] Hayati, Sri, Pengelolaan Lingkungan Hidup Berbasis Masyarakat, Pusat Penelitian Kependudukan dan Lingkungan Hidup-Lembaga Penelitian, Universitas Pendidikan Indonesial, Bandung, 2015.

[5] Iskandar, Johan, Manusia Budaya dan Lingkungan Ekologi Manusia,Bandung: Humaniora Utama Press, 2001.

[6] Keraf, A. Sonny, Etika Lingkungan,Jakarta: Penerbit Buku Kompas, 2006.

[7] Moleong, Lexy J, Metodologi Penelitian Kualitatif, Bandung: Remaja Rosdakarya, 2005.

[8] Neolaka, Amos, Kesadaran Lingkungan, Jakarta: Rineksa Cipta, 2008.

[9] Nucci, P. Larry dan Narvaez, Darcia Handbook Pendidikan Moral dan Karakter, Bandung: Nusa Media, 2015

[10] Santosa, Mas Ahmad, Peraturan Perundangundangan Dalam Lingkungan Hidup, Training Pengelolaan Lingkungan Hidup Bagi Eksekutif, Kementrian Lingkungan Hidup Jakarta, 2004

[11] Sapriya, Pembelajaran Pendidikan Kewarganegaraan, Lap. PKn-FPIPS, UPIBandung 2009.

[12] Sastrawijaya, Tresna. A, Pencemaran Lingkungan, Jakarta, Rineka Cipta, 2009.

[13] Soerjani, Mohamad, Pendidikan Lingkungan (Environmental Education),Jakarta: UI-Press, 2009.

[14] Sulistyaningsih, Tri dan Sunarto, Pengelolaan Ruang Terbuka Hijau Publik Berbasis Demokratisasi peran actor sebagai upaya mewujudkan Kota berkelanjutandi Malang, UMM Press, Malang 2009.

[15] Syahri, M., Pembangunan Berkelanjutan Berbasis Green Moral, Bandung: Widya Aksara Press, 2013.

[16] Syahri, M. dan Handayani, Trisakti, Penguatan Karakter dan Budaya Lingkungan Hidup untuk 
Mendukung Berkelanjutan Energi Terbarukan Micro Hidro, UMM, Malang, 2015.

[17] UU No.23/ 1997 tentang Pengelolaan Lingkungan Hidup

[18] UU No. 32/2009 tentang Perlindungan dan Pengelolaan Lingkungan Hidup

[19] Widjaja, Sutrisna, Pengembangan Model Konseptual Rumah Belajar Lingkungan Hidup (Eco Learning Camp)Sebagai Model Pendidikan Nilai, SPS-UPI, Bandung, 2012. 